\title{
PSYCHOLOGICAL DISORDER PERILAKU ABNORMAL: MITOS DAN KENYATAAN
}

\author{
Antonius Atosökhi Gea \\ Character Building Development Center, BINUS University \\ Jln. Kemanggisan Ilir III No. 45, Kemanggisan-Palmerah, Jakarta Barat 11480 \\ antoniusgea@binus.edu
}

\begin{abstract}
There are a variety of behaviors considered as a deviant behavior (abnormal behavior) because it is different to the behaviors generally accepted in the society. Behaviors considered deviant are determined based on certain criteria, used to assess a behavior as a deviant behavior. Behaviors considered abnormal are classified into specific or difference types. Thus, it is known the name of some kind of abnormal behaviors, in light and heavy level. Important question related to deviant behavior is: whether the symptoms of deviant behavior can be considered as a disease. There are different understandings of the past and the present time. From a medical standpoint (these days), symptoms of a deviant behavior are classified as a disease. If so, then there are actually quite a lot of people suffer from deviant behaviors, because the symptoms described as an abnormal behavior are found in many people, though in different levels.
\end{abstract}

Keywords: abnormal behavior, mental illness, behavior disorder, stress, medical understanding

\begin{abstract}
ABSTRAK
Ada macam-macam perilaku yang dianggap sebagai perilaku menyimpang (abnormal behavior) karena berbeda dengan perilaku yang umum diterima di tengah-tengah masyarakat. Perilaku yang dianggap menyimpang itu ditentukan berdasarkan kriteria tertentu, yang digunakan untuk menilai suatu perilaku sebagai perilaku menyimpang. Perilaku yang dianggap abnormal itu telah diklasifikasikan ke dalam beberapa jenis yang memiliki kekhasan atau perbedaan masing-masing. Dengan demikian kita mengenal nama beberapa jenis perilaku abnormal itu, ada yang kadarnya ringan dan ada yang berat. Yang menjadi pertanyaan penting terkait dengan perilaku menyimpang ini adalah: jika gejala perilaku menyimpang ini dapat dianggap sebagai penyakit atau tidak. Di sini terdapat pemahaman yang berbeda antara zaman dulu dengan zaman sekarang. Dari sudut pandang medis (zaman sekarang), gejala perilaku menyimpang ini digolongkan sebagai penyakit. Jika demikian maka sebenarnya ada cukup banyak orang yang menderita sakit, karena gejala-gejala yang disebutkan sebagai abnormal behavior ini ditemukan pada banyak orang, walau dengan kadar yang berbeda-beda.
\end{abstract}

Kata kunci: perilaku tidak normal, sakit mental, perilaku menyimpang, rasa tertekan, pemahaman medis 


\section{PENDAHULUAN}

Jika kita menyaksikan seseorang dengan tiba-tiba tampil di atas panggung, mulai berpidato dengan berapi-api layaknya seorang presiden, menyampaikan banyak hal yang menunjukkan bahwa sebagai seorang Presiden, dia perlu melakukan banyak hal demi kemajuan bangsanya, pastilah kita mengatakan bahwa orang itu aneh, sudah gila barangkali. Apalagi jika dia sepertinya tidak peduli dengan reaksi orang-orang yang ada di situ, semakin membuat kita yakin bahwa perilaku orang tersebut benar-benar aneh. Kejadian semacam ini banyak ditemukan di mana-mana. Suatu perilaku yang berbeda atau menyimpang dari perilaku biasa yang diterima dalam masyarakat pada umumnya.

Ungkapan psychological disorder jelas berkaitan dengan masalah kejiwaan, tentang adanya gangguan atau kekacauan dalam aspek kejiwaan yang dialami seseorang. Sebetulnya tidak mudah untuk mengetahui adanya keadaan jiwa seperti itu. Namun karena perilaku manusia umumnya merupakan ekspresi dari yang terjadi dalam jiwanya, maka adanya psychological disorder ini ditentukan berdasarkan perilaku menyimpang (abnormal behavior) yang kelihatan, bisa diamati, dirasakan, dan dialami. Dengan mudah kita bisa menyaksikan perilaku yang jelas-jelas berbeda dengan perilaku yang umumnya dianggap sebagai perilaku biasa, yang umum dilakukan oleh banyak orang, yang dianggap sebagai perilaku normal. Perilaku berbeda tersebut dianggap sebagai perilaku menyimpang, dengan tingkat penyimpangan yang berbeda-beda. Selain yang bisa disaksikan dengan kasat mata, sebenarnya ada banyak gangguan kejiwaan yang tidak mudah kelihatan dengan jelas, sehingga tidak mudah menyimpulkannya juga, dan dengan demikian tidak banyak mendapat perhatian.

Dengan berbagai kemajuan yang telah dicapai, khususnya dalam bidang ilmu psikologi klinis, telah dicapai pula kemajuan dalam hal pengembangan pemahaman terkait dengan masalah perilaku menyimpang ini. Artinya, telah ada usaha-usaha untuk menetapkan kriteria untuk menentukan suatu perilaku sebagai perilaku menyimpang. Walaupun ada perbedaan penentuan kriteria antara beberapa ahli klinis, ada beberapa kriteria yang umum digunakan, yang cukup membantu untuk memahami perilaku yang dapat digolongkan sebagai menyimpang dari perilaku normal pada umumnya.

Selain adanya beberapa kriteria yang berhasil dikembangkan dan dapat digunakan untuk menilai suatu perilaku normal atau abnormal, perilaku yang dianggap abnormal telah diklasifikasikan ke dalam beberapa jenis dengan kekhasan/perbedaan masing-masing. Dengan klasifikasi itu, maka perilaku menyimpang yang kita temukan dalam kehidupan sehari-hari dapat digolongkan ke dalam jenis penyimpangan tertentu. Dari pengklasifikasian, setiap penyimpangan telah diberi nama khusus, sesuai atau ada kaitannya dengan gejala-gejala penyimpangan perilaku yang diperlihatkan. Dengan demikian, dikenal nama beberapa kelompok perilaku abnormal, yang di dalamnya terdapat pembagian yang lebih spesifik, yang masing-masing memperlihatkan suatu keunikan penyimpangan tertentu, namun tetap merupakan bagian dari suatu kelompok karena kesamaan dasar perilaku menyimpang yang dimiliki.

Selain adanya kriteria dan juga pengklasifikasian perilaku abnormal, pertanyaan penting yang muncul adalah jika perilaku menyimpang dapat dianggap sebagai suatu penyakit. Dari sudut pendekatan medis (psikologi klinis), perilaku menyimpang atau irasional dikategorikan sebagai sebuah penyakit (illness). Pendekatan medis ini berbeda dengan pendekatan zaman dulu. Perilaku menyimpang tidak dianggap sebagai suatu penyakit, melainkan sebagai takhayul, sehingga orangorang yang memperlihatkan gejala perilaku menyimpang diperlakukan dengan cara yang kurang/tidak manusiawi. Perubahan pemahaman ini sangat terkait dengan pendekatan yang lebih teliti dan ilmiah seputar masalah kejiwaan, khususnya terkait dengan hal yang menjadi penyebab muncul dan berkembangnya gejala kejiwaan yang memperlihatkan diri dalam wujud perilaku abnormal itu. Penyebabnya tidak lagi dianggap sebagai takhayul, melainkah ada beberapa faktor yang bisa menjadi 
penyumbang terjadinya perilaku menyimpang tersebut. Penyebab itu ada yang terkait dengan faktor genetik, dan ada juga yang terkait dengan pengaruh budaya serta pengalaman masa lalu, khususnya pengalaman traumatis. Hal lain yang juga bisa menjadi faktor penyebab timbul dan berkembangnya gejala kejiwaan tersebut adalah terkait pengaruh lingkungan, yang adanya kepekaan terhadap pengaruh lingkungan, khususnya dengan pengaruh bahan-bahan kimia yang membawa dampak bagi kehidupan fisik dan psikis seseorang dengan berbagai macam bentuk dan cara (Baller, 2006).

Dengan pengetahuan yang lebih meyakinkan terkait faktor-faktor penyebab terjadinya gejala gangguan kejiwaan, maka sebenarnya lebih mudah juga untuk menentukan cara penanganannya. Penanganan yang dimaksud di sini terkait dengan masalah pencegahan atau antisipasi, dan lebih-lebih cara memandang dan memperlakukan pasien dalam proses penanganan/penyembuhan. Penanganan yang dikembangkan akan berbeda dengan cara ketika gejala-gejala kejiwaan tersebut lebih banyak dikaitkan dengan takhayul, yang penanganannya biasa dilakukan dengan ritual, semacam doa pelepasan atau pengusiran pengaruh roh jahat terhadap orang yang dianggap sudah terkena gejala itu. Tindakan lain yang biasa menyertai adalah mengasingkan mereka dari kehidupan sosial. Bahkan, tidak jarang mereka mengalami perlakuan lebih kasar, seperti penyiksaan sampai tindakan pembunuhan.

Tulisan ini tidak bermaksud membahas dan menjelaskan semua hal penting terkait masalah kejiwaan dan perilaku abnormal. Tulisan ini menyajikan beberapa informasi awal terkait gejala-gejala, seperti kriteria penilaian, klasifikasi penyakit kejiwaan, serta usaha pendekatan medis. Pada bagian akhir diberikan tinjauan sebagai bahan pemikiran dalam meningkatkan pemahaman terkait penyakit yang sepertinya semakin berkembang ini. Semoga informasi awal ini mendorong para pemerhati masalah psychology disorder dan abnormal behavior untuk mencari tahu lebih lanjut dan mendalam mengenai hal menarik ini.

\section{METODE PENELITIAN}

Penelitian ini dilakukan dengan Library Research. Studi pustaka yang dilakukan menggunakan sumber bacaan yang relevan dan tersedia, berkaitan dengan topik yang hendak dikembangkan. Buku dan artikel jurnal yang berkaitan dengan topik yang dibahas, dijadikan sebagai sumber, baik untuk memahami buah pikiran yang menjadi materi bahasan dalam tulisan ini maupun berbagai kajian atau tanggapan penting dan serius terhadap buah pikiran para tokoh tersebut. Dari berbagai sumber bacaan yang digunakan itu, penulis mengembangkan tulisan ilmiah ini, termasuk memberi tanggapan atau komentar kritis, khususnya pada bagian simpulan.

\section{HASIL DAN PEMBAHASAN}

\section{Kriteria Perilaku Abnormal}

Sepertinya orang mudah saja dalam menentukan suatu perilaku sebagai tidak normal, khususnya jika perilaku itu sungguh sangat kentara keanehannya dibandingkan dengan perilaku biasa pada umumya. Penilaian itu semakin diperkuat lagi apabila suatu tindakan yang kelihatan aneh itu, tidak dimengerti maksud dia bertindak demikian. Akan tetapi, di lain pihak, gejala-gejala perilaku yang tidak kasat mata keanehannya tidak mudah untuk dinilai normal atau tidak normal. Maka pertanyaan penting adalah bagaimana menentukan suatu perilaku itu normal atau tidak normal. Dan pertanyaan lain yang juga penting adalah siapa yang berhak melakukan penilaian itu dan menetapkan hasil-hasilnya. Pertanyaan-pertanyaan penting seperti itu tidak mudah untuk dijawab. Namun, tidak berarti tertutup jalan untuk mencoba mencari jawabannya. Salah satu kelompok profesional bidang 
kesehatan mental, Mental Healt Professionals, telah membuat diagnosis formal tentang psychological disorder. Dalam melakukan diagnosis atas gejala yang kelihatan melalui perilaku-perilaku yang tidak biasa, para ahli psikologi klinis tersebut menggunakan beberapa kriteria yang berbeda satu dengan lainnya. Ada tiga kriteria yang umum digunakan untuk menentukan seseorang menderita psychological disorder. Ketiga kriteria tersebut terdiri atas: deviance, personal distress, dan maladaptive behavior (Weiten, 2002). Berikut penjelasan masing-masing kriteria.

\section{Deviance}

Perilaku yang dianggap menyimpang karena berbeda dengan yang dianggap masyarakat sebagai perilaku yang dapat diterima. Yang disebut normal itu memang ada perbedaan antara satu budaya dengan budaya yang lain. Namun demikian, semua budaya memiliki norma bersama. Dan ketika seseorang melanggar standar norma bersama ini, dia akan dicap sebagai orang yang sakit mental. Contohnya adalah yang disebut transvestic feticism, yaitu suatu perilaku seorang laki-laki akan terangsang secara seksual dengan mengenakan pakaian perempuan. Perilaku ini dianggap sebagai perilaku menyimpang (disorder) secara seksual, sebab perilaku laki-laki yang mengenakan baju perempuan tadi dianggap bertentangan dengan norma dari berbagai aturan budaya.

\section{Maladaptive}

Sesuatu yang dianggap sebagai psychological disorder karena perilaku adaptif harian terganggu/rusak. Artinya, seseorang mengalami masalah dalam hal penyesuaian diri dengan lingkungan sosial mereka. Kriteria ini dianggap sebagai kriteria kunci dalam melakukan diagnosis penyimpangan perilaku para pengguna narkoba. Sebenarnya alkohol atau drugs, dalam diri sendiri bukanlah hal buruk atau penyimpangan. Akan tetapi, ketika penggunaan obat-obat terlarang ini mulai mengganggu kehidupan sosial atau fungsi kerja seseorang, perilaku menyimpang itu menjadi nyata. Dalam hal ini, kualitas maladaptive perilaku tersebut, terutama ketika sudah mulai menjadi ancaman bagi kehidupan sosial di sekitarnya, telah membuat hal itu menjadi peyimpangan.

\section{Personal Distress}

Suatu diagnosis atas psychological disorder yang didasarkan pada laporan seseorang tentang besarnya penderitaan yang dialaminya. Ini adalah kriteria yang tidak biasa, yang dikenakan pada seseorang yang terancam oleh depresi atau kecemasan. Orang yang mengalami depresi, umpamanya, iya atau tidak, mengalami penyimpangan atau perilaku maladaptive. Orang seperti ini biasanya dicap sebagai yang memiliki penyakit (disorder) ketika mereka melukiskan penyakit dan penderitaan subjektif mereka kepada teman-temannya, kepada keluarga, atau kepada siapa saja yang dia temui. Penderitaan subjektif maksudnya penyakit yang lebih merupakan kenyataan dalam tingkat kejiwaan, dan bukan dalam kenyataan faktual fisik mereka.

\section{Klasifikasi Psychological Disorder}

Tidak mungkin bisa mengidentifikasi semua gejala psychological disorder secara bersamasama untuk memahami semuanya dengan baik, dan membuat pengelompokan yang sedemikian ketat atas berbagai jenis dan ragamnya. Namun demikian, usaha-usaha untuk mengidentifikasi dan kemudian mengklasifikasi gejala-gejala tersebut telah banyak dilakukan. Sistem klasifikasi yang telah dibuat terkait dengan mental disorder dapat membantu memfasilitasi penelitian empiris dan meningkatkan komunuikasi di antara para ilmuan, khususnya para ahli psikologi klinis. Maka telah banyak usaha diinfestasikan dalam merencanakan suatu sistem kerjasama untuk membuat klasifikasi yang semakin ilmiah mengenai pychological disorder. 
Usaha-usaha yang dilakukan terkait pelaksanaan diagnosis psikologi untuk perilaku menyimpang secara samar-samar dan informal sebenarnya sudah dimulai pada 1952. Ketika itu Asosiasi Psychiatric Amerika memperkenalkan apa yang mereka sebut Diagnostic and Statistical Manual of Mental Disorder. Ini adalah sebuah sistem klasifikasi psikodiagnostik yang resmi di Amerika. Sistem ini dimaksudkan untuk mencari tahu informasi tentang pasien atas lima dimensi, yakni: clinical syndromes, personality disorder atau mental retardation, general medical condition, psychosocial and environmental problems, serta Global Assessment of Functioning (GAF) scale. Klasifikasi yang dbuat dalam Diagnostic and Statistical Manual (DSM) pertama menyebutlkan ada sekitar seratusan ragam disorder. Kemudian dalam DSM edisi berikutnya (DSM-II, 1968; DSM-III, 1980; DSM-IV, 1994), revisi terhadap sistem DSM telah menambah daftar disorder ini. Dalam tulisan ini tidak akan dibicarakan dua ratusan atau lebih jenis psychology disorder seperti terdapat dalam DSM-IV, melainkan hanya membicarakan beberapa tipe spesifik dari psychological disorder ini (Weiten, 2002).

\section{Anxiety Disorder}

Setiap orang mengalami apa yang disebut anxiety (kegelisahan, kecemasan) dari waktu ke waktu. Itu adalah sesuatu yang alami dan merupakan reaksi biasa terhadap berbagai kesulitan atau masalah yang dihadapi. Akan tetapi, bagi kebanyakan orang, anxiety bisa menjadi masalah kronis. Rasa cemas seperti ini ternyata bisa menjadi gangguan yang sangat parah dan melelahkan dalam kondisi tertentu. Ini bukan lagi rasa cemas biasa atau normal. Orang-orang seperti ini mengalami kecemasan tingkat tinggi yang menggangggu mereka secara konsisten. Jadi anxiety disorders termasuk sebuah penyakit mental yang serius. Orang dengan gangguan ini biasanya memiliki rasa cemas yang besar dan berlebihan, dan sering kali rasa cemas ini melumpuhkannya. Sebenarnya ada cukup banyak orang yang menderita anxiety disorder. Dari studi-studi yang ada terungkap bahwa anxiety disorder sudah umum terjadi, dialami hampir $17 \%$ dari jumlah penduduk dunia (Robin \& Rogier, 1991). Berikut ini beberapa jenis anxiety disorder yang sering dijumpai.

Generalized Anxiety Disorder, yaitu kecemasan berlebihan, yang tidak terikat pada suatu hal tertentu (tidak spesifik). Orang-orang dengan gangguan ini akan cemas terus menerus tentang kesalahan yang telah lewat dan masalah-masalah yang bakal dihadapi esok hari. Mereka cemas tentang hal-hal terkait keluarga, keuangan, pekerjaan, dan penyakit pribadi. Gangguan ini sering disertai dengan gejala fisik seperti gemetaran/menggigil, ketegangan otot, diare, pusing, berkeringat dingin, jatung berdebar, sesak nafas, dsb.

Phobic Disorder, yaitu gangguan kecemasan individual yang memiliki fokus spesifik. Gangguan ini ditandai dengan kekerasan hati dan ketakutan yang tidak masuk akal terhadap suatu objek atau situasi yang tidak memperlihatkan ancaman nyata. Orang-orang dengan gangguan ini memiliki ketakutan terhadap hal tertentu, seperti takut ketinggian, takut darah, takut ular, takut terbang (naik pesawat), dsb.

Panic Disorder, yaitu suatu ganguan yang ditandai dengan serangan kecemasan yang datang secara tiba-tiba tanpa diduga. Serangan melumpuhkan ini sering disertai dengan gejala fisik mudah berkeringat, merasakan sakit di dada, detak jantung tidak teratur, dan perasaan tersedak, yang dapat membuat seseorang merasa seperti sedang mengalami serangan jantung. Pikiran akan terjadinya kepanikan seperti itu di depan umum, orang-orang yang mengidap gejala panic disorder jadi takut untuk meninggalkan rumah.

Obsessive-compulsive disorder; obsessions adalah pikiran (yang umumnya menyusahkan) yang berulang-ulang mengganggu kesadaran seseorang. Sedangkan Compulsions adalah sesuatu hal yang seseorang merasa dipaksa untuk memikulnya. Maka, obsessive-compulsive disorder (OCD) ditandai dengan kekerasan hati, gangguan tak terkontrol dari pikiran-pikiran dan mendesak untuk mewujudkannya ke dalam tindakan tanpa disertai perasaan (senseless). Obsesi sering terarah pada 
tindakan yang merugikan bagi orang lain, gangguan personal, tindakan bunuh diri dan tindakan seksual. Orang-orang yang menderita obsesi biasanya kehilangan kontrol atas pikiran mereka. Mereka memiliki gangguan pikiran yang konstan dan ketakutan-ketakutan tertentu akan sesuatu secara berlebihan sehingga mendorong untuk melakukan sesuatu. Misalnya, orang yang takut pada kuman secara berlebihan sering kali berpikiran bahwa ada banyak kuman di sekelilingnya, sehingga setiap kali ia menyentuh sesuatu, ia harus segera mencuci tangan atau menggunakan pembersih tangan.

\section{Somatoform Disorder}

Somatoform disorder adalah suatu penyakit yang dirasakan secara fisik namun tidak disebabkan oleh gangguan fisik, melainkan faktor psikologis (Yeung, 2002). Seseorang merasa sakit, ada keluhan fisik, namun ketika diperiksa secara medis, tidak ditemukan penyakit fisik seperti yang dikeluhkan itu. Orang-orang dengan keadaan ini banyak ditemukan, mereka mengeluh sakit ini, sakit itu, sehingga mereka seperti dalam keadaan sakit benaran, walau sebenarnya secara fisik mereka tidak memiliki masalah. Somatoform disorder biasanya muncul tiba-tiba dalam kondisi penuh stres, atau ketika seseorang berusaha menghindari suatu tanggung jawab atau mengerjakan hal tertentu. Somatoform disorder bisa muncul dalam beberapa tipe, terutama tiga tipe, yakni: somatization disorder, conversion disorder, dan hypochondriasis.

Somatization disorder ditandai dengan kisah pengalaman beraneka ragam keluhan fisik, yang sungguh hanya secara psikologis saja. Penderitanya sering mengatakan bahwa dia seperti terus berada dalam keadaan tidak sehat. Gejala penyakit ini lebih banyak dialami oleh kaum wanita, dan sering ada bersama dengan depresi dan anxiety disorder (Martin \& Yutzy, 1999). Namun dalam kenyataannya, penderita somatoform disorder menolak untuk membicarakan kemungkinan kaitan antara keluhan fisik yang mereka rasakan dengan masalah yang memberatkan terkait kehidupan mereka.

Conversion disorder ditandai dengan kondisi yang biasanya terjadi pada salah satu panca indra, mengalami kelumpuhan (tidak berfungsi), entah secara sebagian atau secara keseluruhan, walaupun secara fisik pada organ tubuh tersebut tidak terdapat gangguan. Gejala yang bisa terjadi seperti kehilangan pendengaran atau penglihatan atau daya penciuman (sebagian atau keseluruhan). Atau juga, kelumpuhan sebagian atau keseluruhan pada tangan, lengan, merasa kulit gatal atau seperti ditusuk-tusuk, hilangnya kemampuan untuk merasakan sensasi, merasakan sakit tenggorokan atau kehilangan kemampuan bersuara. Kalaupun akhirnya orang-orang ini sewaktu pemeriksaan medis sepertinya terlihat ada ketidakmampuan/kelumpuhan tersebut, namun tidak konsisten dengan fakta yang diketahui tentang penyakit itu secara medis. Artinya, tidak sesuai dengan fakta medis pada umumnya.

Hypochondriasis yaitu suatu gejala seseorang terus-menerus memerhatikan kondisi fisik mereka, memerhatikan tanda-tanda adanya penyakit yang terjadi pada mereka. Sedikit saja mereka melihat ada perubahan, mengantar mereka pada kesimpulan bahwa mereka terkena penyakit. Jadi, hypochondriasis ditandai dengan keasyikan berlebihan memerhatikan kesehatan fisik sendiri dan tak henti-hentinya mencemaskan tentang perkembangan/peningkatan penyakit fisik mereka sendiri. Ada reaksi berlebihan atas sensasi fisik/tubuh, dan mereka sering salah interpretasi atas gejala fisik yang dialaminya. Mereka merasa seperti pusing, otot kaku, jantung berdebar-debar, atau merasa kelelahan, dan seperti tidak enak badan. Hal itu sering mendorong mereka untuk memeriksakan diri ke dokter, periksa diri di lab, dan mengonsumsi banyak obat. Namun ketika dokter meyakinkan mereka bahwa mereka tidak memiliki penyakit yang sesungguhnya, mereka sering skeptis atau tidak percaya. Bisabisa mereka menganggap dokter tadi tidak kompeten dalam mendiagnosis penyakit mereka. Akibat yang cukup terasa dari gejala ini adalah mereka mengalami distress (susah) dan mengalami hambatan dalam fungsi sosial, pekerjaan, dan aspek-aspek penting lainnya yang menghambat perkembangan kesehatan kepribadian mereka. 


\section{Dissosiative Disorder}

Dissosiative disorder merupakan suatu gejala yang tidak biasa, suatu golongan disorder yang seseorang kehilangan kontak dengan bagian dari kesadaran atau ingatan, sebagai akibat gangguan dalam sense of identity mereka. Ada tiga tipe utama gejala penyakit ini, yakni: Dissociative amnesia, dissociative fugue, dan dissociative identity disorder. Dissociative amnesia dan dissociative fugue keduanya merupakan disorder yang overlapping, ditandai dengan berkurangnya/kehilangan ingatan secara serius.

Dissosiative amnesia adalah kehilangan ingatan tiba-tiba akan informasi penting pribadi, yang sedemikian mendalam, yang bisa berujung pada kelupaan sungguhan. Kehilangan memori ini bisa terjadi atas suatu kejadian yang bersifat traumatis, seperti kecelakaan berkendaraan atau kebakaran, atau sekurang-kurang kehilangan ingatan untuk waktu yang lebih lama seputar kejadian itu. Banyak kasus amnesia ini ditemukan pada orang-orang yang mengalami bencana gempa besar, kecelakaan, perang melawan stres, penyiksaan fisik, perkosaan, atau ketika mereka menyaksikan kematian mengerikan dari orang yang mereka cintai, dsb.

Dissosiative fugue adalah keadaan seseorang kehilangan ingatan akan keseluruhan hidup mereka, dan juga kehilangan rasa identitas pribadi mereka. Orang-orang ini bisa tiba-tiba lupa tentang nama mereka sendiri, tentang keluarga mereka, tentang tempat mereka sekarang hidup atau tempat mereka kerja. Jadi mereka lupa sama sekali terhadap hal-hal tertentu terkait pribadi mereka. Anehnya dalam waktu bersamaan mereka malah mengingat hal-hal yang tidak ada hubungannya dengan identitas mereka, seperti tentang cara mengendarai mobil, cara mengerjakan soal matematika, atau yang lainnya.

Dissosiative identity disorder (DID) mencakup hidup berdampingan (coexistence) dalam diri seseorang, dan biasanya sangat berbeda satu sama lain, dan bersifat pribadi. Dissosiative identity disorder bisa jadi berakar dalam trauma emosional yang terjadi sejak masa kanak-kanak. Banyak pendapat mengatakan bahwa DID berkaitan dengan pengalaman masa lalu, dan muncul ketika orang masih kecil/belum dewasa. Ini adalah sebuah mekanisme untuk bertahan terhadap sebuah pengalaman traumatis, yaitu dengan cara dissosiative. Umumnya ini berkaitan dengan pengalaman buruk atau mengerikan. Dengan menggunakan cara ini, seorang anak dapat membuat pikiran sadarnya terlepas dari pengalaman mengerikan yang menimpanya. Jadi penyakit Dissociative Identity Disorder adalah penyakit kejiwaan yang membuat penderitanya memiliki kepribadian ganda dan selalu ingin menjadi orang lain. Jadi DID sebagai kelainan mental membuat seseorang yang mengidapnya menunjukkan adanya dua atau lebih kepribadian (alter) yang masing-masing memiliki nama dan sifat atau watak yang berbeda.

\section{Mood Disorder}

Mood Disorder adalah istilah psikologi yang berarti perubahan mood (suasana hati atau perasaan, gairah) yang tidak sehat atau kacau. Mood disorder adalah sejenis gejala kejiwaan yang ditandai dengan kekacauan/gangguan emosional terhadap berbagai hal yang bisa memengaruhi kondisi fisik, pemahaman/pandangan, hubungan sosial, dan proses berpikir. Pelakunya bisa sangat meluapkan ekspresi berlebih seperti rasa girang yang terlalu besar, atau rasa sedih dan putus asa dan kehilangan minat atas hal-hal yang sebelumnya sangat menyenangkan baginya (keadaan terakhir ini disebut juga sebagai major depressive disorder). Jadi Mood adalah keadaan emosi (state of emotion) yang berlangsung secara relatif, yang penyebabnya sering kali subjektif atau tidak jelas. Jika seseorang merasa takut, itu ada sebabnya, entah faktual atau perceptual (sebab-sebab yang dipersepsikan seseorang). Sama halnya jika seseorang merasa gembira, kegembiraan tersebut muncul karena hal tertentu. Akan tetapi untuk mood disorder, penyebabnya seringkali tidak jelas atau stimulusnya kerap kurang faktual. Misalnya saja, tahu-tahu merasa bad mood saat mau berangkat ke kantor. Mood 
Disorder itu merupakan sisi ekstrem yang sudah tidak sehat (bersifat patologis) dari perubahan mood tertentu, misalnya terlalu girang atau terlalu malang (sadness and elation).

Mood disorder ini memiliki dua tipe utama yakni: unipolar dan bipolar. Orang dengan unipolar disorder mengalami emosi sangat tinggi pada hanya satu puncak dari satu rangkaian emosi (mood) yang berkelanjutan, dan mereka dihinggapi hanya oleh depresi (rasa malang). Sedangkan orang dengan bipolar disorder mengalami emosi sangat ekstrem pada kedua puncak dari suatu rangkaian emosi (mood) yang berlangsung terus, dan bergerak dalam wilayah depresi dan mania (kegembiraan meluap). Untuk jelasnya lihat gambar berikut.

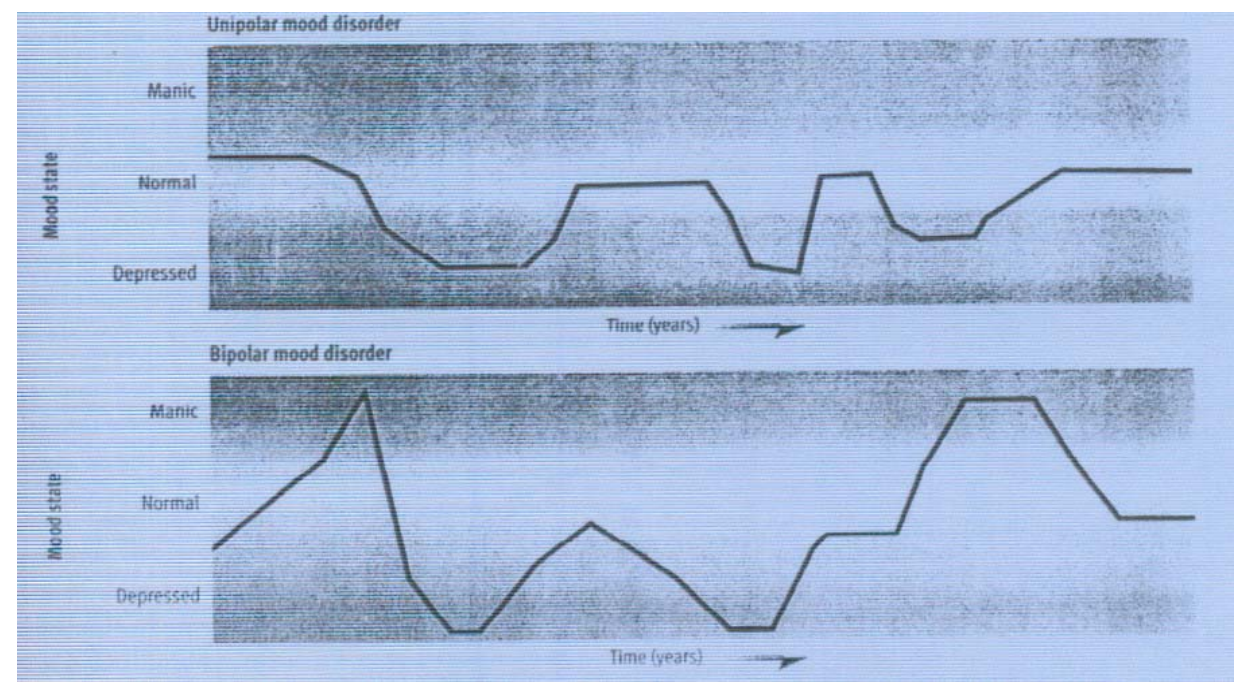

Gambar 1 Mood Disorder

(Sumber: Weiten, 2002: 437)

Sifat-sifat umum yang terjadi pada penderita mood disorder adalah sekali waktu bisa sangat menyenangkan dan bersahabat. Sekali waktu bisa menjadi ketus, galak, pendiam, atau bahkan depresif; sekali waktu sangat optimis, sekali waktu sangat pesimis; berubah mood hanya kerena persoalan yang sebenarnya sepele. Ini terjadi karena tekanan yang lahir dari tafsiran negatifnya terhadap sesuatu. Misalnya dia merasa diburu-buru. Padahal si temannya hanya mengingatkan; menunjukkan kekesalannya dengan curhat kepada teman dekat dan curhat habis-habisan mengenai si A, si B, dan menganggap diri di pihak 'korban'; cenderung tidak menerima saran dan kritik. Dia kelihatan menerima namun dalam hati dia merasa saran dan kritik itu adalah upaya menyudutkannya; dia merasa berhak melakukan apapun termasuk dalam merespons segala hal di sekitarnya. Jika sedang good mood, dia akan menyenangkan semua orang. Namun jika sedang dalam suasana hati yang tidak enak (bad mood), bersiap-siaplah menerima reaksi yang bisa buat kesal; dan jantung selalu berdegup lebih cepat lantaran emosi yang tak stabil, dan bawaannya pengin marah, nangis, kesal, semua campur aduk.

\section{Schizophrenic Disorder}

Secara harfiah, Schizophrenia berarti "split mind" ( jiwa yang retak). Penyakit ini adalah kelompok disorder yang ditandai dengan khayalan, halusinasi, kekacauan berbicara, dan penurunan atau kemerosotan kemampuan perilaku adaptif. Ada banyak gejala yang menyertai penyakit ini. Schizophrenia merupakan gangguan mental kompleks yang membuat orang kesulitan membedakan kenyataan dan ilusi, tidak bisa berpikir logis, tidak mampu mengontrol emosi serta sulit berinteraksi dengan orang lain. Orang dengan schizophrenia dapat mendengar suara yang tidak didengar orang lain 
atau mereka dapat percaya bahwa orang lain membaca pikiran mereka, mengendalikan pikiran mereka atau berencana menyakiti mereka. Pengalaman-pengalaman ini amat mengerikan dan dapat menyebabkan ketakutan, kecanduan atau kemarahan yang ekstrem. Orang dengan schizophrenia dapat berbicara yang tidak masuk akal, dapat duduk selama berjam-jam tanpa bergerak atau banyak bicara, atau dapat terlihat baik-baik saja sampai mereka mengatakan apa yang sebenarnya mereka pikirkan.

Meskipun definisi yang pasti tentang Schizophrenia selalu menjadi perdebatan para ahli, terdapat indikasi yang semakin nyata bahwa Schizophrenia adalah sebuah gangguan yang terjadi pada fungsi otak. Gejala pertama adalah pikiran irasional. Gangguan cara berpikir, berpikir irasional merupakan gejala nyata dari penderita schizophrenia. Kegagalan berpikir mengarah kepada masalah penderita schizophrenia tidak mampu memproses dan mengatur pikirannya. Kebanyakan penderita tidak mampu memahami hubungan antara kenyataan dan logika. Gejala kedua adalah deterioration, yaitu suatu kemunduran dalam hal kualitas fungsi rutinitas seseorang dalam pekerjaan, hubungan sosial, dan perhatian pada diri sendiri, termasuk kurang perhatian pada kesehatannya.

Gejala berikutnya adalah distorted perception. Gejala umumnya adalah halusinasi, mendengar sesuatu yang sebenarnya tidak ada suatu bunyi dalam kenyataannya. Sering mereka mengatakan bahwa mereka mendengar suara yang sebenarnya tidak ada orang yang sedang berbicara kepada mereka. Suara-suara yang mereka dengar itu biasanya bernada negatif tentang mereka.

Gejala berikutnya adalah disturbed emotion, yaitu suatu gangguan emosi seseorang penderita menunjukkan emosi yang datar, hanya memberikan sedikit saja respons emosioal terhadap sesuatu. Atau bisa juga mereka menunjukkan respon emosi yang tidak sesuai, sehingga tidak nyambung dengan situasi atau dengan apa yang mereka katakan.

Tipe utama dari schizophrenia, adalah pertama, tipe Paranoid. Penyakit ini didominasi oleh khayalan akan penyiksaan/penganiayaan, atau juga khayalan akan kehebatan, kemegahan. Mereka percaya bahwa mereka memiliki banyak musuh yang ingin menyakiti atau menindas mereka. Mereka menaruh curiga kepada teman-teman dan bahkan keluarga mereka, atau mereka menghubungkan penyiksaan yang akan mereka alami itu dengan sesuatu yang misterius atau seseorang yang tidak diketahui. Mereka selalu merasa sedang diamat-amati, diintai, atau hendak diserang. Untuk menghadapi penyiksaan itu mereka sering mengembangkan khayalan akan kehebatan/kebesaran yang mereka miliki. Mereka percaya bahwa mereka harus menjadi orang sangat penting. Mereka sering memandang diri mereka sendiri sebagai investor besar, pemuka agama, atau pemimpin politik yang dikagumi.

Kedua, tipe catatonic, yaitu schizophrenia yang ditandai dengan gangguan pada otot, dari kekakuan otot ke berbagai aktivitas otot. Beberapa pasien mengalami bentuk ekstrem dari penarikan diri (withdrawal) yang dikenal dengan nama catatonic stupor. Mereka bisa benar-benar tidak bisa bergerak, dan tampak lupa akan lingkungan sekitar mereka untuk jangka waktu yang lama. Yang lainnya masuk dalam keadaan catatonic excitement (kegembiraan). Mereka jadi hiperaktif dan rada kacau.

Yang terakhir (ketiga) adalah disorganized type. Pada tipe ini, terutama sekali kemunduran hebat pada perilaku adaptif. Gejala mencolok termasuk emosi acuh tak acuh, sering berbicara mengawur, dan benar-benar menarik diri dari lingkungan sosial. Ocehan tanpa tujuan dan terkikihkikih merupakan hal yang biasa pada mereka. Khayalan mereka sering terpusat pada fungsi-fungsi yang bersifat fisik, seperti: "Otak saya mencair dan keluar ke telinga saya”. Artinya, mental atau jiwanya menjadi tumpul, kesadarannya masih jernih, tetapi kesadaran akunya sangat terganggu. 


\section{Pendekatan Medis terhadap Abnormal Behavior}

Pada zaman dulu, orang-orang yang menunjukkan perilaku aneh dianggap sebagai orang yang sudah dirasuki setan atau roh jahat, sebagai takhayul. Teks kitab suci keagamaan banyak memperlihatkan hal itu. Orang-orang yang memperlihatkan perilaku yang dianggap menyimpang dari kebiasaan orang pada umumnya, dan bersifat aneh, dianggap sebagai kerasukan setan atau iblis atau roh jahat atau menjadi korban penghukuman Allah. Perilaku aneh mereka itu ditangani dengan cara mendoakan mereka, melakukan ritual penyembuhan, atau pengusiran setan. Dan bila perilaku orang itu mereka lihat sebagai mengancam, mereka akan dirantai, dikurung di ruang bawah tanah, ada juga yang sampai disiksa, dan akhirnya meninggal secara mengenaskan.

Berkembangnya ilmu pengetahuan medis dalam bidang psikologi klinis telah membawa perbaikan dalam memandang dan memperlakukan orang-orang yang memperlihatkan perilaku abnormal. Sebagai korban dari berbagai penyakit, mereka dipandang dan diperlakukan dengan sikap lebih empati, tidak dibenci dan ditakuti. Walaupun kondisi hidup mereka pada awalnya menyedihkan, bersamaan dengan keadaan yang menyedihkan itu terdapat perhatian yang lebih manusiawi bagi mereka yang secara mental sakit. Memang membutuhkan banyak waktu, namun pendekatan yang sepertinya dari awal dianggap sebagai yang tak berguna, pada akhirnya membuka jalan pada investigasi ilmiah lebih lanjut mengenai penyebab dan juga obat atas psychological disorder ini.

Akan tetapi, pada dekade terakhir ini, terdapat beberapa kritik/tinjauan atas medical model ini terkait kegunaannya. Salah satu kritik muncul umpamanya dari Thomas Szasz (1974-1990). Dia mengatakan bahwa dengan lantang bisa dikatakan bahwa disease atau illness hanya dapat menguasai badan, dan oleh karena itu tidak ada yang disebut mental illness. Pikiran (mind) dapat 'sakit' hanya dalam arti kiasan, seperti halnya juga sakit dalam hal ekonomi. Belakangan beliau mengatakan bahwa perilaku abnormal biasanya merupakan penyimpangan dari norma sosial ketimbang sebagai penyakit (illness). Ia mengatakan bahwa penyimpangan itu adalah permasalahan kehidupan ketimbang sebagai permasalahan medis. Menurut Szasz, secara analogi pendekatan medis telah mengubah pertanyaan moral dan sosial tentang apa itu perilaku yang dapat diterima, menjadi pertanyaan medis (Szasz, 1974: 267).

Walaupun kritik dari Szasz memiliki manfaat, penyakit sebagai analogi tetap dapat digunakan, meskipun tetap harus diingat bahwa itu hanya sebuah analogi saja. Yang jelas, dengan usaha pendekatan medis yang telah banyak dilakukan, maka konsep medis seperti: diagnosis, etiology, dan prognosis memiliki nilai yang sudah terbukti dalam usaha menguraikan dan belajar tentang abnormalitas psikis atau perilaku ini. Diagnosis termasuk membedakan suatu penyakit dengan penyakit yang lain. Etiology merujuk pada penyebab yang jelas dan sejarah perkembangan dari suatu penyakit. Prognosis berupa perkiraan mengenai kemungkinan terjadinya suatu penyakit. Konsep yang didasarkan pada pendekatan medis ini memiliki arti yang tersebar luas yang memungkinkan para ahli klinis, peneliti, dan masyarakat umum untuk berkomunikasi secara efektif dalam diskusi mengenai perilaku abnormal yang sudah merupakah kenyataan dimana-mana dan sepanjang sejarah manusia.

Dari hasil kajian medis dan berbagai diagnosis psikologis yang dilakukan dalam waktu yang cukup lama, dan melibatkan banyak ahli, dapat ditemukan bahwa berbagai jenis penyakit mental tersebut, yang menghasilkan perilaku-perilaku abnormal yang kelihatan maupun tidak kelihatan, disebabkan oleh banyak faktor. Faktor tersebut adalah psikologis dan biologis (genetik), pengaruh kepribadian, budaya, pengalaman masa lalu, khususnya pengalaman-pengalaman traumatis, serta kondisi lingkungan tempat tinggal, penggunaan obat-obat terlarang, dsb. Selain itu, ada yang disebabkan oleh salah satu faktor saja dan ada juga berupa kombinasi dari beberapa faktor. Mengenai faktor yang menjadi penyebab untuk setiap jenis mental disorder tidak dibahas dalam tulisan ini, karena ada banyak keterangan yang perlu disajikan berkaitan dengan hal itu, sehingga lebih cocok disajikan dalam tulisan khusus lainnya. 
Dengan dapat diidentifikasikannya faktor penyebab timbulnya penyakit kejiwaan yang muncul dalam berbagai jenis penyakit itu, maka lebih mudah juga untuk menentukan cara-cara penanganan yang akan diambil, baik dari tindakan antisipasi pencegahan maupun penanganan setelah terjadi gejala. Sama halnya dengan faktor penyebab dari penyakit tersebut, demikian juga halnya dengan cara penanganan atau lebih tepat pendampingan kepada para penderita penyakit kejiwaan tersebut tidak disajikan dengan rinci dalam tulisan ini. Yang jelas penanganan bagi para penderita psychology disorder tidak dilakukan seperti pada zaman dulu, penderita banyak diperlakukan secara tidak manusiawi, karena dianggap perilaku aneh yang mereka perlihatkan terjadi karena si penderita telah dirasuki oleh setan, sehingga perlu ditakuti dan dijauhi. Sekarang ada banyak cara penanganan yang dapat dilakukan, oleh pribadi maupun lembaga yang meyediakan jasa pelayanan bagi para penderita masalah kejiwaan, yang sebelumnya telah dibekali dengan pengetahuan dan keterampilan khusus untuk menjalankan terapi psikologis dan medis-klinis bagi para penderita masalah kejiwaan.

\section{SIMPULAN}

Sebuah kenyataan bahwa terdapat banyak jenis perilaku menyimpang (abnormal behavior), suatu ekspresi dari masalah yang sebenarnya terletak dalam dimensi jiwa manusia (psychology disorder). Kriteria yang ada telah membantu untuk mengidentifikasi jenis penyimpangan ini. Namun juga, walaupun kriteria itu bisa diaplikasikan dalam kasus khusus, banyak terjadi orang sering dipandang sebagai yang "menyimpang” ketika satu dari kriteria itu terpenuhi. Biasanya, diagnosis yang dilakukan meliputi juga penilaian tentang perilaku normal atau abnormal. Akan tetapi, kriteria yang digunakan untuk penyakit mental tidaklah semudah menilai penyakit fisik. Dalam menilai suatu penyakit fisik umpamanya, orang lebih mudah setuju bahwa jantung yang lemah atau ginjal yang tidak berfungsi adalah penyakit, tanpa ada lagi penilaian subjektif mereka. Beda halnya jika menilai penyakit mental, akan diikutsertakan refleksi nilai-nilai budaya, kecenderungan sosial, dan kekuatan atau tekanan politik, termasuk juga pengetahuan sains (Weiten, 2002: 427).

Terkait dengan penetapan kriteria penilaian sakit mental ini para psikologi evolusioner telah mengusulkan bahwa mental disorder harus dipandang sebagai disfungsi perlahan yang berbahaya. Menurut pandangan ini, disfungsi terjadi ketika suatu mekanisme psikologi tidak melakukan fungsi seleksi alamiahnya secara mencukupi atau secara efektif. Sebagai contoh, perasaan gelisah muncul/berkembang karena dia meningkatkan kewaspadaan organisme untuk aneka ancaman. Akan tetapi, ketika seseorang secara kronis cemas tentang segala sesuatu namun tidak ada ancaman nyata, di sini mekanisme psikologi tidak bekerja secara efektif.

Dasar pemikiran bagi argumen evolusioner ini adalah bahwa ketika mekanisme psikologi telah dilukiskan dan fungsinya diidentifikasi, kriteria penilaian harus tersedia (dapat digunakan) untuk menentukan apa yang menunjukkan suatu disfungsi. Sementara menurut Wakefield (1992), kriteria objektif ini akan melawan pelabelan sewenang-wenang dari masyarakat, yang dengan mudah menilai suatu gejala perilaku tertentu sebagai penyakit (disorder). Teori evolusioner telah menyediakan sudut pandang segar, namun kritik telah memperlihatkan keraguan tentang apakah pendekatan ini sungguh dapat menghasilkan kriteria objektif dari psychological disorder (Fulford, 1999). Satu problem kunci adalah bahwa ada ruang debat tentang apa persisnya fungsi dari aneka ragam mekanisme psikologi itu.

Lawan kata seperti normal dan abnormal, mental health dan mental illness menyatakan secara tidak langsung bahwa orang dapat dibagi secara ketat atas dua kelompok berbeda: mereka yang disebut normal dan mereka yang tidak (abnormal). Padahal dalam kenyataan, sering sangat sulit menarik garis pemisah yang jelas antara kenormalan dan ketidaknormalan. Pada suatu saat setiap orang bertindak dalam cara yang menyimpang, setiap orang menunjukkan beberapa perilaku 
maladaptive, dan setiap orang mengalami kesusahan pribadi. Orang hanya bisa dinilai sebagai memiliki psychological disorder hanya ketika perilaku mereka menjadi menyimpang secara ekstrem, maladaptive dan menyusahkan secara keterlaluan. Dengan demikian, kenormalan dan ketidaknormalan berada dalam satu bentangan (dari yang sederhana sampai yang tinggi). Itu adalah masalah tingkatan, bukan salah satu ada atau tidak ada.

Walaupun tetap menggunakan beberapa kriteria penilaian, sesungguhnya tetap saja sulit untuk memastikan dengan baik antara perilaku yang termasuk normal dan tidak normal. Artinya, ketika suatu perilaku dihadapkan dengan kriteria-kriteria yang ada, tidak langsung menjadi jelas kepada kita bahwa perilaku itu termasuk tidak normal. Bisa-bisa terjadi bahwa kita salah menilai. Kita bisa menilai suatu perilaku sebagai yang abnormal atau menyimpang hanya berdasarkan kriteria yang berhasil kita tetapkan, padahal perilaku-perilaku itu terkait atau melibatkan banyak hal, budaya, pendidikan, pengalaman, genetic, dsb, yang bisa saja dari sudut pandang hal-hal itu perilaku tersebut sebanarnya normal-normal saja. Itu artinya kriteria-kriteria yang berhasil ditetapkan itu tak pernah dianggap mencukupi, melainkan lebih sebagai usaha (yang terus berlangsung) untuk lebih mengerti perilakuperilaku itu yang menunjukkan perbedaan dari perilaku-perilaku yang umum di diterima dalam masyarakat.

Sebuah kemajuan yang membanggakan telah dicapai dalam usaha memahami masalah terkait psychological disorder. Dengan kemajuan yang dicapai itu, dalam penetapan kriteria, dalam identifikasi jenis-jenis penyimpangan, dalam penelusuran sebab-sebabnya, dan dalam merancang penanganan bagi para penderita masalah kejiwaan, membuat antisipasi dan terutama pendampingan bagi para penderita masalah kejiwaan semakin baik dan manusiawi. Sulit dibayangkan jika pemahaman dan perlakuan seperti zaman dulu masih tetap diterapkan; suatu kesalahan besar yang tidak habis untuk disesalkan. Maka, semakin menarik untuk meneruskan pendalaman banyak hal terkait masalah psychological disorder ini.

\section{DAFTAR PUSTAKA}

Baller, J., et al. (2006). Syndrome stability and psychological predictors of symptom severity in idiopathic environmental intolerance and somatoform disorders. Psychological Medicine, 2007, 37, 271-281.

Beck, A. T., (1997). Cognitive Theraphy: Reflections. In J. K. Zeig (Ed.). The evolution of psychotherapy: The third conference. New York: Brunner/Mazel.

Bowen, R. C., Senthilselvan A, Barale, A. (2000). Physical illness as an outcome of chronic anxiety disorders. Canadian Journal of Psychiatry, 45, 459-464.

Fulford, K.W.M. (1999). Nine variations and a coda on the theme of an evolutionary definition of dysfunction. Journal of Abnormal Psychology, 108, 412-420.

Martin, R.I., \& Yutzy, S. H. (1999). Somatoform disorder. In R.E. Hales, S.C. Yudofsky \& J.A. Talbott (Eds.), American Psychiatric Press Texbook of Psychiatry. Washington, DC: American Psychiatric Press.

Pope, H. G, Jr., Oliva, P. S., Hudson, J. I., Bodkin, J. A., Gruber, A. J. The American Journal of Psychiatry; Feb 1999; 156, 2; ProQuest Research Library, pg. 321. 
Robins, I., N, \& Rogier, D., A. (eds.). (1991). Psychiatric disorders in America: The epidemiologic catchment area study. New York: Free Press.

Szasz, T. (1974). The myth of mental illness. New York: Harper \& Row.

Wakefild, J. C. (1992). The concept of mental disorder: On the boundary between biological facts and social values. American Psychologist, 47, 373-388.

Weiten, W. (2002). Psychology. Themes \& Variations, Fifth Edition, Briefer Version. Belmont, USA: Wadsworth - Thomson Learning.

Yeung, A., Deguang, H. Somatoform disorder. Western Journal of Medicine, Sep 2002, 176, 4; ProQuest Research Library, pg. 253. 